\title{
Pakpak Ethnic Values That Are Relevant To Leadership
}

\author{
Din Oloan Sihotang, Darwin \\ SMK Swasta Arina Sidikalang,Universitas Negeri Medan \\ oloansihotang81@gmail.com, darwin.dbep@gmail.com
}

\begin{abstract}
This study aims to find out the Pakpak ethnic values that are relevant to leadership. The study was conducted in Dairi regency. The data collection technique in this study is the study of literature by gathering various information through the internet, which is further examined by conducting interviews with the subjects of the Pakpak traditional leaders. The findings of the research are 4 (four) Pakpak ethnic values that are relevant to leadership, namely: a) the value of knowledge; where Pakpak ethnic leaders are someone who must have self-knowledge by having an attitude of introspection, not harming others, being responsible, honest, easy to adapt and become a motivator, and able to build commitment to achieving goals, b) religious values; on this dimension, a leader is required to rely on God in every action, c) Social Value; In this dimension an ethnic leader is formed in an organizational structure called Sulang Silima, and d) Physical Values; In this dimension a leader has a standard of worthiness, has a strong and healthy physique.
\end{abstract}

Keywords: value, ethnic Pakpak, leadership

\section{Introduction}

North Sumatra Province is one of the multiethnic provinces in Indonesia with ethnic Batak, Nias, Malay, and Minangkabau as indigenous people of this region. The eastern coastal area of North Sumatra is generally inhabited by Malays. The central region around Lake Toba, inhabited by many Batak tribes, most of whom are Christian. Nias tribe is located in the western islands. Since the opening of tobacco plantations in East Sumatra, the Dutch East Indies colonial government brought in many contract laborers employed on plantations. Most of the migrants came from Javanese and Chinese ethnic groups. Pakpak Batak ethnic/ethnic groups are names of ethnic groups that have different characteristics from other ethnic groups in Indonesia. The area of origin of the population of the Pakpak ethnic group is the area of Dairi Regency and Pakpak Bharat. Traditionally the community area is called Tanoh Pakpak. The smallest community in the Pakpak tribe is called Lebuh and Kuta. Lebuh, a part of Kuta which is inhabited by small clans, and Kuta is a combination of more than one inhabited by a particular clan (clan), which is considered a native, while certain clans are categorized as migrants. The Pakpak people adhere to the Patrilineal principle in calculating lineages and the formation of kin groups called clans. Thus the implications for the dominant inheritance system are for boys only. The form of marriage is exogamy of clans, meaning that someone must marry outside 
his clan and if marrying a person as high as is considered to violate adat because it is categorized as incest. The Pakpak tribe is often classified as a Batak sub ethnic group. The Pakpak ethnic group is bound by a social structure that is in local terms with sulang silima. These five elements play an important role in the decision-making process in various aspects of life, especially in kinship systems, traditional ceremonies and in the context of more or more communities. This means that these five elements must be involved so that decisions taken are valid by custom. Ethnic Pakpak has always had characters written in a book called "LAPIHEN". In Lapihen book there are various notes in the form of spells, religious and others in the Pakpak regional language. In the Pakpak ethnic structure in the past it was known that there was a layer of society called the layer of custom leaders, world leaders or secular elite groups (Berutu, 2006: 4). This leader will be seen in every ethnic pakpak event, such as at the Njahat Work (Grief Ceremony) and Good Work (Joy Ceremony). Adat and the social structure of the Pakpak Tribe family called "Sulang Silima".

\section{LITERATURE REVIEW}

\section{History of Pakpak Ethnic Birth}

Historically, the origin of the Pakpak tribe was from South India, from India Tondal who later settled in Muara Tapus near Barus City and then developed in Pakpak land and later became the Pakpak tribe. Basically, the ancestors of the Pakpak tribe have had clans from their home countries, but later formed a new clan that was not much different from the original clan. Not all Pakpak people live in Pakpak land, but they are also diaspora, leaving their country and settling in new areas. Some live in Pakpak land and become Pakpak tribes. They became "Situkak Rube", Sipungkah Kuta, and Sukut Nitalun on Pakpak land. Some go to other regions to form new communities. They learned that the origin was from the Pakpak area and claimed that Pakpak was his tribe, but had become a clan in another tribe. Based on the dialect and distribution area, Pakpak can be classified into five major parts, namely: Pakpak Simsim, Pakpak Keppas, Pakpak Pegagan, Pakpak Boang and Pakpak Kelasen (Berutu, 2018: 5-6). Each sub is differentiated based on the customary rights of the clan who administratively do not only live or settle in the Dairi Regency area (before it is divided), but there are those in Aceh Singkil, Humbang Hasundutan (before being divided from North Tapanuli) and Central Tapanuli.

\section{Community Structure}

The community is composed of the Marga-marga (65 clan) who inhabit each ulayat land rights which is a unity with his life led by Pertaki and then on it is' Aur led by a King. The community structure is placed in the SILIMA SULIMA consisting of the Central Bussines (Middle Brothers) PEREKUR-EKUR (pardons / youngest) PERBETEKKEN (berru) and PUNCA NDIADEP (Puang kula-kula). This division of status has an important role in society especially in relation to the status of a person who should be included in the Sulang Silima. The questionnaire has a very broad role as the saying goes "Bana bilalang Bana birru, Bana ulubang guru bana" has the 
advantage of being Commander of the War, King of Adat and as Teacher who is a role model and role model for his community.

\section{Land Customary Law}

Land is a unity with Pakpak society's life or shows identity of the community members so that the land determines the life of the community. The land is dominated by the clan as the owner of the land. The forms of soil as follows:

- The land was not exploited, namely "Longo-longoon Land", "Land of Nuclear Land", Land of the Old Land, "Tanah Balik Batang" and Rambah Keddep ".

- The land is "Tahuma Pargadongen", "Permenenjenen", and "Bungus".

- Perpulungen lands are the embals, Jampalan, and Jalangen.

- The land of Sembahen, the land of magical (sacred) land consists of the land of Sembahen Kuta (not cultivated) and land of Sembahen Balillon (can be cultivated).

- The Land of the Destroyer is a land that is designated as a cemetery.

- Land Inventory is the land of the land where the land remains the land, the land is maintained by Permangmang (the oldest group) and must not be disturbed.

\section{Pakpak Ethnic Leadership Values}

When we speak of cultural values, we must first open the space to equate views about the concept of cultural values with culture. Cultural values are part of culture. While culture is a broader concept than just cultural values. For this reason, before discussing cultural values, it is better to discuss the concept of culture first. Thus, our understanding of cultural / cultural values becomes more focused. The cultural values possessed by one community can consist of several value categories, namely the value of knowledge, religious values, social values, artistic values, and economic values (Wibowo, 2014: 5). In the category of social values there are a number of values, such as orderly values, loyal friends, self-esteem, help, harmony, competition, discipline, and so on. The value of discipline is also an element of religious value, in addition to taqwa, faith, which is an element of artistic value in addition to beautiful, melancholic, subtle, cheerful, dynamic, creative, and others. In other words, a spread or several values as elements in the category of values: knowledge, religion, social, art, and economics. The whole values are related to one another, so that it is a cultural value system. In this mini research, the leadership values of leadership values contained in Pakpak ethnicity are as follows: 


\section{a. Knowledge Value}

In ethnic groups Pakpak knows proverbs that actually describe the identity / character of the community, which is also called 'peddah' or advice. According to Tumangger (2000) advice is the number three truth level in the ethics of Pakpak. The first level of truth is Revelation from God. The second level of truth is the Ten Commandments of God. The third level of truth is Peddah or advice.

\section{b. Religious Value}

At this time the Pakpak community has embraced Islam and Christianity, although previously it was very strong against animist beliefs (pelebegu) but this shows a very rapid change in this belief, even though there are still certain beliefs. Tolerance between followers of the Religion is high because it is bound by family.

Religious values in ethnic Pakpak are increasingly thickening, visible in every work (party) always starting with a prayer ritual to the creator led by Pakpak traditional leaders.

\section{c. Social Value}

Pakpak ethnic groups have a high social life. The nature of mutual cooperation is still maintained in the Pakpak community. This is reflected in everyday life together.

This is manifested in the following form

- Abundant, namely a form of cooperation in rice cultivation and others, the implementation begins with "merkua", namely by first notifying one by one the family of the community to be able to work together to complete a work, for example "mardang" (planting rice )

- Urup-urupen is a collaboration to complete a job with several families so that the work is completed. For example, a family invites one other family to work together on their fields

- Merkua, which is a form of communication that occurs between adat leaders and residents in one lebbuh. Merkua is one of the distinctive characteristics of ethnic Pakpak. Merkua is carried out in a place called 'sapo /sopo or meeting room. That's where residents discuss and communicate to resolve problems or seek consensus.

\section{Dimensions and Indicators of Pakpak ethnic leadership values}

From the Pakpak ethnic leadership values, the indicators of Pakpak ethnic leadership values can be seen in the table below. 
Table 2.1 Dimensions and Indicators of Pakpak ethnic leadership values

\begin{tabular}{|l|l|l|l|}
\hline No. & Values & Dimension & Indicators \\
\hline 1 & $\begin{array}{l}\text { Knowle } \\
\text { dge }\end{array}$ & Wise & $\begin{array}{l}\text { - Self-Intention } \\
\text { - Not harming yourself } \\
\text { and others } \\
\text { - Adaptable } \\
\text { - Easy to learn new } \\
\text { things }\end{array}$ \\
\hline 2 & $\begin{array}{l}\text { Religiou } \\
\text { s }\end{array}$ & $\begin{array}{l}\text { Relations } \\
\text { with God }\end{array}$ & $\begin{array}{l}\text { - Rely on God } \\
\text { - Spiritual health }\end{array}$ \\
\hline 3 & Social & $\begin{array}{l}\text { Organization } \\
\text { al Relations }\end{array}$ & $\begin{array}{l}\text { - Deliberation } \\
\text { - Mutual cooperation } \\
\text { - Like helping } \\
\text { - Communicative }\end{array}$ \\
\hline 4 & Physical & Strength & $\begin{array}{l}\text { - Ability to use } \\
\text { physical } \\
\text { - Physical Health } \\
\text { - To be responsible }\end{array}$ \\
\hline
\end{tabular}

\section{METHODOLOGY}

This research method is descriptive qualitative. The survey subjects in this study were people who had extensive knowledge of Pakpak ethnicities, such as; Chairperson of Customary / Indigenous Leaders, and Head of the local Tourism Service The data collection technique in this mini study is a literature study technique by collecting various information through the internet, which then investigates deeper information by conducting interviews with research subjects, and collecting documentation. Indepth interviews focused on four things, first, data tracking to get an idea of the concept and meaning of Pakpak's cultural values related to the leadership system based on the understanding of the supporting community, namely the Pakpak community. This also concerns the background, purpose and function of cultural values for Pakpak ethnic groups. Data analysis techniques are from the results of observations and in-depth interviews and then combined with data obtained through literature studies conducted by researchers. These literatures are mainly related to Pakpak cultural values that have been written by previous researchers 


\section{RESULT AND DISCUSSION}

\section{A. Results}

Pakpak ethnicity has traditionally been called Tanoh Pakpak. Traditional Tanoh Pakpak is divided into five customary regions, namely:

a. Simsim (in Dairi district and Pakpak Bharat district)

b. Keppas (in Dairi district and Pakpak Bharat district)

c. Gotu Kola (in Dairi district and Pakpak Bharat district)

d. Class (in Parlilitan sub-district Humbang Hasundutan district and Manduamas and Barus sub-districts, Central Tapanuli district)

e. Boang (in Aceh Singkil district and Subulussalam city)

The 5 regions above are traditionally referred to as Tanoh Pakpak, which although different regions, but traditionally is basically not separated from each other, besides that all administrative regions are still directly adjacent. The Pakpak community social organization system is regulated in the Sulang Silima structure which consists of 5 elements: Sinina situaen (oldest brother), Sinina Penengah (middle brother), Sinina Sikedeken (youngest brother), Puang (girl giver relatives) and Berru (girl recipient relatives). These five elements play a very important role in the decision making process at the jabu level (nuclear family), sada bapa and sada empung (extended family), community (kuta), or clan. The five elements can be grouped into three broad categories, namely: Sinina, Puang and Berru. For Sinina there are two types, namely Sinina as high as (on the father's side) and Sinina not as high (on the maternal side). Based on the level and scope of roles and functions it can be categorized as 5 types of sima silima, namely: Sulang Silima Jabu; meaning five elements are at the level of the nuclear family. Sulang silima Sibeltek Father; meaning five elements are at the level of the extended family, especially the brothers. Sulang Silima Sibeltek Mpung; means that it is at the level of the wider family, especially the grandparents. Sulang Silima Lebbuh; means that it is at the level of the kin group which is calculated based on the male line of a community of relatives of a larger clan that can be categorized as a small class. Sake Silima clan. Means that it is at the level of certain clans, for example the genus Bancin, Manik, Berutu and other Pakpak clans. Sulang silima sarga for example consists of: Sukut (Mangmang, sinabul, sikuraja), Puang (Tinambunen and Tumangger) and Berru (Bancin and Munthe). From the description it can be concluded that Sulang Silima Pakpak is obviously absent because Pakpak's clans are from different ancestors of one clan with another clan. The following briefly describes the role and function of the creep in the Pakpak culture / customs. In the kinship systems the various rights and obligations in the marriage system range from restrictions and determination of mate, debt, custom merbayo and backlash. They also set the customs of kinship (pertuturen). In the 
traditional ritual of the fifth element of the crimson is very decisive, both custom ceremonies throughout the life cycle rites as well as other custom ceremonies. In the decision-making process at the core family level, extended family, wealth, fortune, and clan greatly determine the legitimacy of a decision. For example in the determination of a custom ceremony, a bramble, a brick wall and even a swing. Transfer of rights and obligations. Distribution of inheritance at core family level, extended family and transfer of land rights to other clan or clan group (rading berru). Settlement of disputes. Disputes in core families, large family disputes, land disputes, overdue disputes, kuta disputes, disputes of the clan are usually very important because the settlement of the five elements is more generally recognized and legally.

From the functions and roles of Pakpak's above-mentioned above it is clear how their position plays a leader in every town / village. They are always present in every custom ritual and important activity of each one (relatives) and have an important role in decision making. Thus the Pakpak etiquette has the dimensions of values relevant to leadership. Among them are the value of knowledge, religion, social, and physical values.

\section{Knowledge Value}

In ethnic Pakpak know proverbs that actually describe the identity / character of the community, which is also called 'peddah' or advice. The value of other knowledge that can be used as a guide for a leader in acting is "repeat telpus bulung" meaning "the leaves should not be torn or leaked". The everyday meaning that a leader does not harm himself and others. From the results of the interview above, the dimensions of leadership value from the aspect of knowledge is that a leader is required to have an attitude of self-awareness or caution, not harming others, being responsible, honest, adaptable and motivating.

\section{Religious Value}

Pakpak ethnic groups embrace various religions or beliefs. The majority are Islam and Christianity, although at the beginning of the emergence of ethnic Pakpak previously was very strong against animist beliefs (the pelebegu) or idol worshipers. Tolerance between followers of the Religion is high because it is bound by family. Religious values in ethnic Pakpak are increasingly thickening, seen in every work (party), always starting with prayer rituals to the creator led by Pakpak traditional leaders or now being led by religious leaders. From the results of the interview above, the dimension of leadership values from the religious aspect is that a leader is required to rely on God in every action. This means that a leader sees something with his heart and has confidence in the person he leads as he believes in his God.

\section{Social Value}

Pakpak ethnic groups have a high social life. The nature of mutual cooperation is still maintained in the Pakpak community at every traditional ceremony. Traditional ceremonies are traditionally referred to as work or work. In everyday language it is often also called the party. 
From the results of the interview above, the dimensions of leadership values from the social aspect are a leader who has a helpful nature, works together, cooperates, deliberates, is responsible and has a plan.

\section{Physical Values}

If the cultural values give direction to human behavior and actions as a leader, then the guidelines are firm and concrete. This is evident in the norms, laws and rules From the results of the interview above, the dimension of leadership value from the physical aspect is that a leader has a standard of feasibility, has a strong and healthy physical, has charismatic, physical and responsible health.

\section{B. Discussion}

A cultural value system (or a cultural system) is a series of abstract concepts that live in the minds of most citizens (Pelly, 1994). It concerns what he considers important and valuable. In Indonesia, an anthropologist, Koentjaraningrat (2004), in his studies accommodates these two perspectives. According to him Culture is the whole system of ideas, ideas, activities and human works that are shared and obtained through the learning process.

\section{Knowledge Value}

Culture is the result of human work, which includes the results of human reason, taste, and will. Therefore, culture never stops, continues throughout the ages, is a process that requires a long time to fulfill the human desire to be more qualified. If culture is the work of humans, then knowledge as a result of human reasoning is also a culture. But knowledge can be said to be the end result in human mental development and can be considered as the most optimal result in human culture.

A good leader is required to have knowledge to hone the sensitivity of a leader in dealing with HR problems, marketing, production, finance, and changes that occur in his company with agility, and how they can become strategic change leader (Shelmi, 2011: 8-9)

From the findings of the interview with Shelmi's statement (2011), the dimensions of Pakpak's ethnic leadership values from the aspect of knowledge are leaders who are required to develop their own knowledge by having an introspective or cautious attitude, not harming others, being responsible, honest, adaptable and being motivator, and able to build commitment to achieving goals. Possess an attitude that is able to handle, understand problems and take opportunities quickly, visionary, and able to combine various information to get a complete perspective

\section{Religious Value}

Regarding the statement of Koentjaraningrat (2004: 85), under the seven elements of universal culture, according to him, it consisted of: language, knowledge systems, livelihoods, equipment and technology, social organizations, arts, and religion. Leadership Is Influence, which is a person's ability to influence others. People can only lead others as long as they can influence them. This fact is supported by the 
definitions of leadership formulated by people who have a large influence. Spiritual leadership is a mixture of natural and spiritual qualities. Even natural properties do not just arise, but are given by God, and therefore these qualities will achieve the highest effectiveness, if used in leadership with the aim of serving the Creator and for the glory of God. This is the finding of the interview with Edis Ujung, the Pakpak ethnic leader who mentioned the first level of ethnic Pakpak truth is God's Revelation, the second level of truth is the decree in the Qur'an / Bible. So that from the interview findings and their relationship with Koentjaraningrat's theory (2004: 85) that the pakpak ethnical value that is relevant to leadership from the religious dimension is that a leader is required to rely on God in every action. This means that a leader sees a problem with his heart and influences the people around him by referring to the decree given by God as a guide to life and leadership.

\section{Social}

Koentjaraningrat (2004: 86) says in the social sciences the concept of culture can actually be divided into two major paradigms namely: cognitive paradigm and behavioral paradigm. Experts who adhere to the cognitive paradigm explain culture as what is perceived and thought by humans as part of certain groups of society. Thus it means abstract nature because it includes ideas, knowledge, rules and laws. In Pakpak ethnic traditional ceremonies traditionally referred to as work or work.In everyday language it is often also called the party. In every Pakpak ethnic party, must be attended by customary elements confiscated in the structure. The Pakpak community social organization system is organized in the Silima sulang structure which consists of 5 elements: Sinina situaen, Sinina Penengah, sinina sikedeken, Puang, and berru. These five elements play a very important role in the decision making process at the jabu level (nuclear family), sada bapa and sada empung (extended family), community (kuta), or clan (klen).In conjunction with the Koentjaraningrat theory (2004), from the results of interviews with Pakpak traditional tokok, the similarity of dimensions of leadership values from the social aspect is that ethnic leaders in Pakpat are formed in an organizational structure called sulang silima. And a leader has a helpful nature, works together, cooperates, deliberates, is responsible and has a plan.

\section{Physical Values}

In individual interactions with other individuals there will be many possible psychological impacts that occur, for example the process of adaptation, the process of competition, cooperative attitude, imitation, solidarity, identification, influence of suggestion, etc. The leader is loved and hated, while being praised and chided. The big burden that is on his shoulders, makes him the foundation of the great hopes of the overall public interest (Hasim, 2018: 1). From the conclusions of the interview results and Hasim (2018) and Bahri (2009), the dimensions of Pakpak ethnic tilapia that are relevant to leadership from the physical aspect are a leader who has a standard of feasibility, has a wise physical, strong and healthy, has charismatic, physical health and be responsible because the big burden is on the leader who makes him the big support of the people around him. 


\section{CONCLUSION}

From the findings of the interviews and several studies of leadership theory, Pakpak's ethnic values are relevant to leadership in terms of several aspects, such as:

\section{a. Knowledge Value}

In this dimension, a leader is required to develop his own knowledge by having an attitude of introspection or caution, not harming others, being responsible, honest, easy to adapt and become a motivator, and able to build commitment to achieving goals. Procces an attitude that is able to handle, understand problems and take opportunities quickly, visionary, and able to combine various information to get a complete perspective.

\section{b. Religious Value}

In this dimension, a leader is required to rely on God in every action. This means that a leader sees a problem with his heart and influences the people around him by referring to the decree given by God as a guide to life and leadership.

\section{c. Social Value}

In this dimension an ethnic leader is formed in an organizational structure called sulang silima. And a leader has a helpful nature, works together, cooperates, deliberates, is responsible and has a plan

\section{d. Physical Values}

In this dimension, a leader has a standard of worthiness, has a wise physique, is strong and healthy, has charismatic character, is physically fit and is responsible because of the great burden on the leader who makes him the big support of the people around him.

\section{Implications}

In conjunction with leadership science, Pakpak ethnic Sulang Silima which is dominated by three main classes (Sinina situaen, Sinina Penengah, Sinina Sikedeken) is categorized as the oldest class that is likened to a top manager, the middle class is compared to the middle manager and the smallest class. Managers who each have their respective functions and roles coordinating with each other.

\section{Suggestion}

First to the goverment og Pakpak residents and the relevant principals, carry out maintenance and security of the ancestral remains that are in excess, both physical and non-physical relics. For example by establishing a Museum, Bale and Library. And specially for the local governments should consistently provide facilitation to 
local institutions such as: groups of artists, groups of artisans and others related to the preservation and development of Pakpak customs and culture.Further, to the next need deeply study related to Pakpak issues and their culture or provide facilitation for relevant experts.

\section{References}

Berutu, Lister, 2006. Customs and Marriage Procedures of the Pakpak Community, Medan: Grasindo Monoratama

Berutu, Sri Ayu 2018 The Meaning of Customary Wedding Clothes Pakpak (Online) Http://Repositori.USU.ac.id/Handle/123456789/7067

Wibowo, 2014. Performance Management, Fourth Edition, Rajawali Press, Jakarta. pp 5

Kardoman Tumangger. 2008. Pakpak Tribe and Its Existence in Indonesia. http://kardomantumangger.blogspot.com/2008/08/suku-pakpak-dan-eksistencydi.html accessed March 3, 2019

Pelly, Usman, 1994, Theory - Socio-Cultural Theories, Educational Development and Quality Improvement Projects, Directorate General of Higher Education and Culture

Koentjaraningrat. 2004. Introduction to Anthropology. Jakarta: Rineka Cipta

Shelmi. 2011. "Change Management Strategies for Successful ERP Implementation." Business Process Management Journal, 7 (3), 266-275

Hasim, 2018, Human Culture and Environment Anthropological Review, Student Library, Yogyakarta

Bahri Sadat. 2014. Leadership is a Mental Game. [online] http://ik overview.com/ leadership-is-dis-mental/ accessed June 32019 